\title{
Populism and the Italian Electorate: Towards a Democracy without Parties?
}

\author{
By Domenico Fruncillo*
}

The Italian political system has undergone significant changes over the past two or three decades. One of the most interesting attempts to interpret this change draws on the notion of populism. In Italy, as in many other countries, the electoral success of populist parties and movements has attracted considerable attention. This paper aims to assess whether the ascent of these political forces corresponds to the diffusion of 'populist' opinions and attitudes amongst citizens. In the first part of the paper, the crisis of the party-dominated Italian political system is analysed, and the conditions in which populist formations gained acceptance are described. The new political actors are introduced, with particular emphasis on their populist traits. The second part of the paper assesses whether certain elements of populism are shared by Italian citizens, including proximity to political parties, trust in representative institutions, the need for a strong leader and attitudes towards immigrants. In addition, based on the assumption that populism is a thin ideology, which can be integrated with strong and structured ideologies, the hypothesis that different forms of populism can be identified within the electorate, in line with their position on the Left-Right spectrum, is examined. Feelings of aversion towards political parties are relatively widespread within the electorate, whilst antipathy towards immigrants is most marked amongst right-wing sympathisers. The need for a strong leader appears to be shared by voters, and this perception also includes those who identify with the Left.

Keywords: democracy, immigrants, leaders, political parties, populism

\section{Introduction}

During the 1990s, the Italian political system underwent profound transformations, assuming new characteristics that are often contradictory and difficult to decipher. One of the most interesting attempts to interpret these changes revolves around the concept of populism. In this paper, I adopt the hypothesis that populism is at the same time a determinant and an effect of the crisis of the political parties as representative bodies. It is noteworthy that populist political forces have affirmed themselves so rapidly in Italy, one of the countries in which political parties had most powerfully penetrated society and state institutions during the post-war period. Scholars have suggested that Italy is the "richest laboratory" for studying populism (Zanatta 2002: 286), and "one of the preferred terrains of populism, as a mature and far from marginal phenomenon" (Tarchi 2003:7, 2015: 8).

In order to assess whether populism is truly useful in order to describe the changes in the Italian political system, it is necessary to specify the contours of

\footnotetext{
${ }^{*}$ Research Fellow and Assistant Professor, University of Salerno, Italy.
} 
this concept and its main elements. This operation is far from straightforward, as populism is a "catchall term" (Mény 2004: 360) which is often used to gather up heterogeneous empirical examples, with the result that it risks becoming vague, ambiguous and inflated (Mastropaolo 2005).

The "appeal to the people as a foundation of the political order" (Tarchi 2003: 16) is the "strong nucleus" of all manifestations of populism. More precisely, populism entails "an appeal to the people against the prevailing structure of power and against the ideas and values that dominate society" (Canovan 1999: 3). It is "an ideology that considers society as being divided into two homogeneous and antagonistic groups, the 'pure people' and the 'corrupt élite'" (Mudde 2004:543). In Italy, the parties are the fulcrum of the power structure. For a long time, they have controlled the functions of government, occupied the state bureaucracy and exerted influence over public and private companies, professional and occupational associations and even recreational organisations. The political class that emerged from this partydominated system was the backbone of the "corrupt" élite. For this reason, a strong aversion to parties is one of the traits of Italian populism that I analyse in this paper.

Populism is an appeal against the dominant ideas of society, including those which govern the system of representative politics. This expresses itself through complex and interlocking procedures which make decision-making a lengthy process. Populists demand immediate answers to problems and thus favour a simplification of the processes through which decisions are taken and decision-makers are selected. The figure of the leader assumes a decisive role for the realisation of an immediate and non-mediated politics. Indeed, the leader - the principal decision-maker - is in a direct relationship with the people and personifies their virtues.

Another element in the operative definition of populism used here is connected to the notion of the people which is defined in different ways by the various movements 1 . The people is a homogeneous totality. It is not formed by aggregating individuals who share objective conditions such as a job or profession, but is constituted through processes of cultural reworking. It includes all those who feel bound by the same destiny (Tarchi 2004: 421) and excludes two kinds of enemy: the élite, above, and foreigners, below. The élite is an enemy of the people (when understood as "ordinary" or "common"), just as foreigners are enemies of the people (when understood as a specific kind of "nation" or "community").

Antipathies towards foreigners are therefore important when seeking to distinguish right-wing populism from left-wing populism. The first expressions

\footnotetext{
${ }^{1}$ Margareth Canovan discusses four possible meanings of the term "people": united people (a whole population), ordinary people (which is self-explanatory, and is opposed to the privileged élite), common people (workers, poor individuals) and ethnic people (a specific community) (Canovan 1993: 54-57, 1999: 5). Mény and Surel propose three meanings, depending on whether one is referring to the distribution of power between a sovereign ruler and his/her people, of wealth between a dominant class and the rest of the population or to the geographical or blood-related union of people and nation that is constructed by history (Meny and Surel 2004: 173-196).
} 
of populism in Italy adopted the definition of the people as a national or ethnic unity and were hostile to immigrants. However, more recent political formations which are not situated to the right of the ideological spectrum express a strong opposition to parties and representative politics, emphasise the role of the leader but are nevertheless more open and tolerant towards immigrants. These two elements - hostility towards a corrupt élite or towards immigrants - thus define populism through the negative identification of the "enemies of the people".

The third trait used here to define populism rests with its positive assessment of the figure of the strong leader, which shows not only what populism opposes, but also what it favours. In the logic of populism, the leader does not simply represent the citizens' interests, but actually personifies the people and incarnates their hopes, expectations and fears. The leader can take decisions quickly because he or she has a direct connection with the people and is not conditioned by the structures of representation, rules and procedures which govern decision-making in representative democracy. Populism thus presents itself as a form of democratic government, but without the parties.

In the next section, I will illustrate the crisis of the Italian party-dominated system, from which the new political actors emerged. I will then describe the populist formations themselves, taking account of the aspects described in this introduction. In the second part of the paper I will assess whether any or all of these populist themes are shared by Italian citizens, as I indicated earlier. In particular, I will examine sentiments towards the political parties, trust in the system of representation, calls for a strong leader and attitudes towards immigrants. To this end, and in analogy with the analysis of political actors (Tarchi 2015), I will seek to verify whether it is possible to identify distinct forms of right-wing and left-wing populism amongst voters.

\section{The Crisis of the Party-Dominated System and the "Success" of Populism}

The political parties were the true protagonists in the consolidation of Italian democracy. From the end of World War II onwards, the democratic regime was characterised by a substantial stability and continuity in the party system. The pillars of this system were the Christian Democrats (DC), a proAmerican and overtly Catholic formation, and the Italian Communist Party (PCI). These two parties regularly obtained two-thirds of the vote at elections and created a bipartite system which has been defined "imperfect" (Galli 1966) due to the fact that the DC and PCI did not, in fact, alternate in government. The PCI remained consistently an opposition party, although it was involved in collectively assuming certain strategic decisions in crucial moments of the history of Italy. For more than 40 years, Italy was considered "one of the countries in which the influence of parties on government was greatest"(Calise 1994: 6), and successive governments were supported by varying coalitions controlled by the DC. 
Nevertheless, at the beginning of the 1990s, this system collapsed like a giant with clay feet (Cotta and Isernia 1996). In these years, official investigations led to the discovery of a diffuse system of corruption and illicit funding of parties, leading to the decapitation of the party managers who had sustained government at local as well as central level. Above all, the investigations triggered a powerful wave of popular outrage and stimulated a widespread anti-party sentiment. In the same period, the proportional electoral system was overturned by popular referendum. An almost majoritarian law was subsequently approved, which was intended to favour the transition towards a system that would favour the alternation of governing political forces (Calise 1998), based on the so-called "Westminster model" (Ljiphart 2001).

That collapse was not an unexpected event, but rather the spectacular finale of a process which had been germinating for several years. The first symptom was the decline in electoral turnout. After the foundation of the Italian Republic, electoral participation had been consistently high. At the end of the 1970s, however, it entered a phase of gradual erosion, signalling a crisis in the relationship between citizens and political parties (Fruncillo 2004).

The crisis of the political parties in Italy was due to changes involving the citizens as well as the parties. It has been argued that cultural transformations involving "cognitive mobilisation" weakened the bonds between citizens and parties (Dalton 1984). According to this hypothesis, as education levels improved, and as citizens gained access to a wider range of information, they acquired the competence and resources necessary to engage with the political sphere without the mediation of the parties.

On the other hand, the Italian parties had become progressively "more remote from the everyday life of the citizens" (Mair 1992: 103) as they deepened their occupation of the institutions (Katz and Mair 1995), giving rise to an extreme form of party rule (partitocrazia). In general, this has been defined as a form of government in which "one or more parties have a monopoly over access to government personnel, resources and policies" (Lowi 1992: 299). In this way, the mass parties in Italy had contributed to democratising government. However, as they occupied not only the governing institutions, but also the state bureaucracy, public enterprises and means of communication (starting with the state broadcasting company, RAI).

It would be interesting to describe in greater detail the processes which contributed to configuring the Italian party-dominated political system and the various aspects which were responsible for its ruinous collapse. It is sufficient, however, for the purposes of the present analysis, to emphasise the proliferation of particularistic provisions in defence of specific interests which accentuated the country's economic crisis (Cotta and Isernia 1996). In this situation, the parties were no longer able to respond to the requests of the citizens, as judicial investigations brought to light the true extent of the moral degradation of the politicians who had risen to the top of the political parties.

Feelings of hostility towards the political parties spread rapidly, heralding in a period of "antipolitics" (Mastropaolo 2000). The protagonists of this phase were the parties who, until that moment, had been excluded from government: 
on the one hand, the Left-wing Democrats (PDS) and Communist Refoundation (RC) which emerged from the dissolution of the PCI, and on the other, the MSI-DN party which identified with the ideological tradition of Italian fascism.

The economic and financial crisis required a drastic reduction in public spending. As a result, many citizens faced the apparent impossibility of improving their situation, which is generally considered a fertile terrain for the diffusion of populism or the success of populist appeals (Di Tella 1997). The diffidence towards the political parties had increased rapidly, as I noted earlier, following the identification of numerous episodes of corruption involving important party representatives. In this context, the institutional strength of the parties and their pervasive occupation of the state apparatuses, which had previously been tolerated, was now increasingly perceived as excessive or even illegitimate. Disaffection gradually gave way to hostility towards and aversion to the political parties. In short, what had looked like the strongest form of domination by political parties until the 1980s entered rapidly into crisis and was challenged by new and "populist" political actors.

From the 1990s, the term "populist" was frequently used in Italy in the course of political debates and by journalists, albeit with different meanings and intentions and often in a derogatory way. Scholars started to use the notion of populism to describe general or systemic tendencies, the positions and inclinations of new political actors and the current orientations of the old parties or their heirs.

The political career of Silvio Berlusconi, ex-President of the Council of Ministers, has been studied as an example of European neo-populism. The rich media tycoon entered the political arena in 1994, founding the movement Forza Italia and winning the elections. With alternating fortunes, he also became President of the Council of Ministers after the 2001 and 2008 elections. He had emphasised his distance from the "political circus" ${ }^{2}$ and railed against 'professionals' of politics. By contrast, he presented himself as a successful businessman and even in 2006 "focused his campaign for re-election on the notion that communists, journalists and great businessmen had formed an improbable alliance to take control over the country" (Jones 2007: 37).

Berlusconi had already shown his intolerance for the procedures of parliamentary democracy, which he characterised as "political liturgy". His preferred alternative was to propose simple solutions for highly complex problems, making numerous promises, as populist outsiders typically do (Mastropaolo 2005). For example, he promised to create a million new jobs, to lower taxes and to raise pension payments. Personalisation was his principal resource in gaining consent, and he presented himself as lively and energetic, the undisputed leader of a broad coalition. He was often successful in simplifying the political confrontation and transforming it into a sort of referendum (or plebiscite?) on his own personal role.

The characteristics of Berlusconi's political and electoral proposals were well-suited to the production routines and communication codes of television.

\footnotetext{
${ }^{2}$ This expression (teatrino della politica) was frequently used by Berlusconi.
} 
As many commentators have observed, television prefers binary forms of communication which are linked to individual personalities (Mazzoleni and Sfardini 2009, Mazzoleni et al. 2003). Berlusconi was particularly skilled in making optimal use of television with a view to gaining electoral consensus. He demonstrated all of the natural gifts of a born communicator, and was wellplaced to exploit the advantages inherent in his objective situation. He was owner of the largest private television network in Italy and, particularly during the period in which he was head of government, enjoyed a benevolent treatment from the public radio and television company RAI.

Over the course of recent years, other populist forces have appeared on the Italian political scene. Researchers distinguish between "organisations in which the 'populist' dimension is stronger [the Northern League], in the sense that it plays a stable role in structuring their position within the party system, their fundamental ideological orientations and mode of functioning and [...] parties or movements for which the 'populist' variable plays a secondary or episodic role" (Mény and Surel 2004: 239-240), where the latter category includes Alleanza Nazionale, Forza Italia, the Girotondi movement, the political formations inspired by the ex-magistrate Antonio di Pietro and the Movimento 5 Stelle, promoted and animated by the comic Beppe Grillo (Tarchi 2015).

The Northern League, since its origins at the end of the 1980s, appealed to the virtuous people of Northern Italy against the corrupt national political class based in Rome. At the beginning of the 1990s, the League sustained and exploited the investigations of the Milanese magistrates, contrasting the honesty of the people with the corruption of national politicians. It talked up the 'ethnic' diversity of the North (popolo padano) and even threatened secession. The hostility of the League towards the South, which was accused of wasting the resources produced by an industrious North was matched by a position of closure and discrimination against migrants, described as delinquents and accused of stealing jobs from Italians and polluting the culture of autochthonous populations. Umberto Bossi was for many years the charismatic and undisputed leader of the League, even after being hit by serious illness. Bossi left the leadership of the party when he was involved (together with a number of close relatives and collaborators) in scandals regarding the use of public funds attributed to the Northern League.

Alleanza Nazionale was founded following the dissolution of the Movimento sociale italiano, in an attempt to move from a political formation strictly linked to the fascist tradition to a party linked with the modern European Right. It assumed several populist traits, including a strong reliance on the charisma of its leader, an emphasis on the intrinsic meaning of the Italian nation and a hostile attitude towards migrants.

In recent years, movements and political organisations that may be defined populist have also emerged on the political Left. Some of these movements such as the movement of the Girotondi ${ }^{3}$ - never participated in elections, whilst

\footnotetext{
3 This movement took shape following an initiative of the well-known left-wing cinema director, Nanni Moretti. Like many other observers, Moretti attributed Berlusconi's victory in 2001 to the divisions which had prevented the Centre-Left from contesting the elections united
} 
others have obtained a small share of the vote. An example is Italia dei valori, the political party founded by one of the magistrates who had led the investigations against corruption at the beginning of the 1990s. Despite their relatively weak electoral performance, these examples illustrate the capacity of populist rhetoric to penetrate Centre-Left parties.

The first common element shared by these movements is their polemical opposition to and mistrust of the organisational structures and personnel linked with the political parties. For example, the Girotondi were born when, during a political initiative following the 2001 elections, Nanni Moretti took the floor to invite leaders of the Centre-Left parties to "go home", as they had failed to place the demands of Centre-Left voters above their own self-interests. For this reason, exponents of these political movements avoid using the term "party" in their logos (e.g. Italia dei valori, Sinistra ecologia e libertà, Girotondi).

A striking investment in the role of the leader and his or her capacity to motivate a popolo (people) is the second characteristic which unites these movements. The clearest example is that of Antonio Di Pietro, the exmagistrate and founder of Italia dei valori. He presents himself as a sort of preacher of justice against the corrupt and opportunists. This party and its capacity to attract votes were closely linked with the leader's national profile. Indeed, when Di Pietro was the target of journalistic investigations, which revealed the superficial way in which party funds were managed, his image was weakened and the party practically disappeared from the political scene.

The third trait of these political formations is their abandonment of a classbased ideology in favour of demands for a radical transformation of society. The political actor which best exemplifies this aspect is Sinistra ecologia e libertà (SEL). This left-wing party was created by the Communist Refoundation party ${ }^{4}$, which was headed by the ex-President of the Puglia Region, Nichi Vendola, part of the Green Party (i Verdi) and the Democratic Left (Sinistra Democratica), a small formation that had abandoned the Leftwing Democrats (DS) ${ }^{5}$ when the latter merged with the Margherita ${ }^{6}$ to form the Democratic Party (PD). SEL had abandoned its far left origins and assumed the characteristics of a hybrid formation embracing several different political traditions which identified with a rather generic programme of radical change.

behind a single banner. Above all, he accused the leaders of Centre-Left parties of ignoring Berlusconi's judicial problems and the evidence of corruption and tax evasion which magistrates had uncovered. However, the movement rapidly lost steam and did not evolve beyond a series of demonstrations and similar initiatives.

4 This party had been founded following the dissolution of the PCI, as an avowedly "neocommunist" party which refused to abandon the legacy of the PCI and refused to enter the Partito democratico della sinistra (PDS).

${ }^{5}$ The Democratici di sinistra was an evolution of the PDS following the dissolution of the PCI.

${ }^{6}$ The Margherita was the result of a fusion between the Partito popolare and the Democratici. The former was founded following the crisis and subsequent dissolution of the Christian Democrats, whilst the latter brought together politicians with a liberal Catholic background, followers of the ex-President of the Council of Ministers, Romano Prodi. In 1996, Prodi had led the Centre-Left coalition to electoral victory, but was later substituted as head of government by other coalition leaders, first Massimo D'Alema and then Giuliano Amato. 
SEL dissolved recently and its members have given rise to a new formation, Sinistra italiana, which also attracted a number of dissidents from the Partito democratico. The fortunes of SEL were, for most of its history, dependent upon the success of its leader, Nichi Vendola. Predictably, his own political eclipse coincided with the political and electoral decline of this formation.

The 5-star Movement (Movimento 5 stelle) is a new-entry in the Italian political scene. Nevertheless, at its first national electoral test in 2013, it was the party that attracted most votes ${ }^{7}$. Activists of this movement refuse to position themselves on the traditional Left-Right spectrum ${ }^{8}$. In fact, it is difficult to locate the 5-star Movement in these terms by referring to issues that typically define the Left-Right distinction in politics (Kitschelt 1988, Knutsen 1998). Many scholars consider the 5-star Movement as a populist political formation (Natale 2014, Tarchi 2015), and its trademark is outright hostility towards the political "caste".

This aversion is characterised by two distinct elements, the first of which is "honesty" - the movement's battlecry - which is viewed as an essential condition for assuming any political office. The second element relates to the status of elected representatives, who are not accorded greater power or influence than other members of the movement, on the basis of the principle uno vale uno ("one equals one"). By contrast, the political caste is accused of appropriating unearned and unwarranted privileges vis-à-vis ordinary citizens.

The 5-star Movement expresses dissatisfaction with the procedures of representative democracy, at least in terms of the forms that this has taken in the past. It has proposed a binding mandate for elected representatives and supports a model of participation based on instruments of direct democracy. The movement evokes and occasionally uses these kinds of mechanisms to reach decisions on policies and positions. This aspect can be interpreted in different ways, and some scholars have linked it with populism (Taggart 2002: 183): "The basic message of every form of populism is its refusal of mediations that are judged useless, superfluous, limiting or harmful" (Taguieff 2003: 85). The 5-star Movement shares this sense of mistrust in representative politics, and its founder and real leader is not directly involved in any representative institutions.

This synthetic description of the Italian political scene, as it has evolved over recent decades, demonstrates that populism has gained strength, as it has diversified and spread across the political spectrum (Tarchi 2015). The various expressions of populism in Italy share a negative attitude towards representative politics and the main actors who have animated this scene for the past 40 years, namely the political parties. Furthermore, all populist forces

\footnotetext{
${ }^{7}$ The 5-star Movement received 8.69 million votes, whilst the PD received 8.64 million. However, the Centre-Left coalition, comprising not just the PD, but also SEL, Centro democratico and the Sud Tiroler Volkspartei (SVP), obtained more votes and thus received a block of additional seats, in line with the provisions of the electoral law. As a result, the PD currently has the largest number of seats in Parliament.

${ }^{8}$ See, for example, Grillo (2013), Il M5S non è né di destra né di sinistra, retrieved from http://bit.ly/2fYVNx1 [Accessed 4 June 2014]
} 
attribute a powerful role to the leader, to whom they entrust themselves. There are nevertheless differences according to whether populist parties are located on the Centre-Left or Centre-Right, with the latter being more explicitly hostile towards immigrants.

\section{Populism: Mere Rhetoric or (Thin) Ideology?}

The description provided in the previous pages of the crisis of the partydominated system (partitocrazia) and the Italian political system in general showed that populist leaders and formations are now well-established in Italy. One of the aims of this paper is to assess whether, and to what extent, "populism is popular" (Mény and Surel 2002: 2). This can be determined, in the first place, by examining the degree of electoral consensus these parties are able to achieve. However, the various parties adhere to populist principles to different degrees and in different ways, emphasising only some of the aspects implied by the theoretical model of populism outlined earlier. Moreover, we cannot exclude the possibility that voters may have chosen these parties for other reasons, such as solidarity towards a specific social group or familiarity with a candidate.

More reliable indications can be gained from the analysis of opinion data from surveys. In this way, it is possible to assess whether the Italians are populists and what proportion of the population may have internalised or assimilated the ideology of populism. Several studies have looked at political actors, including the behaviour of leaders and the publications, internal documents and electoral posters of various political forces (Rooduijn et al. 2014). On the other hand, few studies have examined the diffusion of populist themes at a mass level, looking beyond the political élite, and there is a distinct lack of measures and methods to tackle this specific task.

Some scholars hold that this aim should be abandoned, as populism is a fleeting concept that "lacks a coherent definitional basis" (Woods 2014: 1). Difficulties also arise from the way in which the term populism is used almost exclusively in a derogatory manner, to denigrate political opponents. Simplistic declarations and opportunistic policies are often labelled as 'populist', based on the assumption that they seek to appease voters and achieve their approval whilst ignoring superior policy alternatives (Mudde 2004: 542). And in scientific research, the term populism has a long history of use as an evaluative concept9. Over time, however, scholars have stopped treating populism as a pathology, although some researchers still view populist mobilisations as falling somewhat outside the canons of liberal democracy.

It has been noted that the term "populism" is essentially ambivalent. Its root contains the word "popolo", which represents "a clear link with the democratic idea, whilst the suffix "ism" signals an ideological charge which is in contrast with the moderate character of contemporary democracies" (Decker

${ }^{9}$ For a review of the literature which relies on a derogatory definition of populism, see Taguieff (2003, 41-76). 
2003: 48). This term signals an alteration in the equilibrium on which liberal democracy is based. Populism thrives when the gap between the two faces of democracy - the redemptive and the pragmatic - widens, and may be viewed, in this sense, as a "shadow" of democracy (Canovan 1993, 1999).

At the same time, populism has been considered a symptom of the poor health of democracy (Mény and Surel 2004), although it is also interpreted less as a threat than as a challenge to liberal democracies, and one that is able to promote their evolution in a truly "popular" direction (Decker 2003: 48). This is arguably the only research perspective that is capable of overcoming the prescriptive approach that has characterised a considerable share of scientific research on the theme, as well as influencing wider debates. In order to assess at what level the challenge of populism against the liberal democracies lies, it is necessary to clarify if populism is a syndrome (Wiles 1969), a style (Taguieff 2003), a mentality (Tarchi 2003: 21, 2015: 52) or an ideology (Mény and Surel 2004, Taggart 2002, Canovan 1981, Zanatta 2002). Naturally, the possible arguments in favour of each of these positions are manifold.

In this reflection, I adopt the hypothesis that populism is an ideology and not merely a discursive style or political strategy (Woods 2014). Nevertheless, it is possible to attribute to the term "populist ideology" a broader or narrower meaning or one which is more or less structured (Crosti 2004: 427-429, Mudde 2004: 543). Adopting an inductive (rather than deductive) approach, one scholar has proposed to consider populism as "thin ideology", that is "as a bundle of loosely interrelated ideas that are not comprehensive systems of thought rooted in political theory, but are rather conceived of as interpretive frameworks that emerge as a result of the practice of putting ideas to work in language as concepts" (Stanley 2008: 98). We are dealing, in other words, with ideologies "that do not provide answers to all the major socio-political questions, and could therefore be compatible with other, more extensively developed political belief systems, such as socialism or liberalism" (Stanley 2008:98).

\section{Populism among Voters}

The considerations made so far have contributed to clarifying that populism is a "thin ideology". This set of ideas seems to accompany liberal democracy like a shadow which is more visible when the balance between the redemptive and pragmatic faces of democracy enter into crisis or, in other words, when the pillar of the popular will is neglected in liberal-democratic regimes in favour of the constitutional pillar. Populism could be a reaction to or a product of - the growing distance between citizens and government institutions (Stetter 2013: 1). Thus, it is a sign of the malaise of democracy or a challenge to it.

In the first part of this article, a definition of populism was proposed, identifying the fundamental, but essential, core (the appeal to the people), along with some specific traits: aversion to political parties, emphasis on the 
leader as a resource for structuring relationships between the people and decision-making, hostility towards migrants. On this basis, it is possible to develop an analysis of voters' opinions.

The results of sample surveys conducted by the Istituto Cattaneo, within the Itanes programme (Italian National Election Studies), for every national election since 1972, are used. This analysis refers to the 2001 and 2008 findings ${ }^{10}$.

In 2001, the survey was conducted between May 18 and June 18 (the elections were held on Sunday, May 13) with a sample of the Italian adult population, consisting of 3,209 people, via "face to face" interviews using CAPI (Computer Assisted Personal Interview) techniques. The reference population comprises all Italians aged 18 years and over ${ }^{11}$. In 2008, the survey was carried out between April 17 and May 20 (the elections were held on April 13, 2008), on a sample of the Italian adult population, consisting of 3,000 people, through telephone interviews using CATI (Computer Aided Telephone Interview) techniques. The reference population is again represented by all Italian adults, aged 18 years and over ${ }^{12}$.

The analysis conducted on the basis of the two post-election surveys makes it necessary to clarify further the proposed operational definition of populism. In the introductory part, it was pointed out that an "appeal to the people" is the "strong core" of a populist ideology. The people are a fundamentally homogeneous totality that includes "only those who are considered the 'real' people" (Mény 2004: 368-369). Clearly, it is a typical construction and mechanism of collective identities that allows identification of a "we", who feels part of the people, marking the distance from "others" who

\footnotetext{
${ }^{10}$ I would like to thank the scientific directors (Paolo Bellucci and Marco Maraffi) and the entire Itanes research group for allowing me to use the data.

${ }^{11}$ Regarding gender, there is a greater presence of men in the sample $(50.3 \%)$ compared to the population (47.9\%); with reference to age and gender, there is an under-representation in the sample of women aged between 18 and 24 years $(5.3 \%$ in the population and $4.1 \%$ in the sample), and particularly among women over the age of 75 years $(6.0 \%$ in the population and $3.1 \%$ in the sample); on the contrary, there is an over-representation of men aged between 55 and 64 years $(6.9 \%$ in the population and $7.9 \%$ in the sample). Regarding level of education, there is an under-representation of people who have only a primary education $(32.7 \%$ in the population and $23.9 \%$ in the sample) and an over-representation of those who went to secondary school $(24.9 \%$ in the population and $32 \%$ in the sample) or university $(7.2 \%$ in the population and $9.0 \%$ in the sample). For this reason, the data were re-weighted before processing in order to reduce these differences between the sample and population.

${ }_{12}$ Regarding gender, there is no difference between the shares of males and females in the sample and in the population; with reference to gender by age, there is an under-representation of women over 75 years ( $7.2 \%$ in the population and $5.0 \%$ in the sample); there is an underrepresentation of men aged between 35 and 44 years $(9.9 \%$ in the population and $8.0 \%$ in the sample) and in men over 75 years $(4.2 \%$ in the population and $3.1 \%$ in the sample). Regarding education level, there is an under-representation of people who have only a primary school education (26.6\% in the population $17.5 \%$ in the sample) and an over-representation of those who studied at secondary school $(36.4 \%$ in the population and $44.1 \%$ in the sample). For this reason, the data were re-weighted prior to processing in order to account for these minimal differences between the sample and population.
} 
are enemies of the people, amongst whom are the exponents of mediation and representation structures (Gellner and Ionescu 1969).

For decades, the parties were able to give life to sufficiently receptive and responsible governments. They "were at the same time representatives and rulers" (Mair 2002: 83-84). The party government kept the popular and constitutional pillars in balance. The popular pillar legitimised political decisions since it was based on the will and preferences of the people. The constitutional pillar, which is the set of rules and procedures, ensured the balance between powers and reduced the risk of "excessive power" of the people. In essence, the parties were assured that the government was "by" the people (input-oriented) and even "for" the people (output-oriented) (Mair 2002: 82).

The political parties were able to transfer the will of the people into policy decisions since they were well-established in society and could capture its instances and moods. From a certain point onwards, however, the parties focused their attention and energy on their role in the institutions and became further and further removed from the lives of the citizens.

Judicial investigations have contributed to further undermining their credibility. However, the main changes are related to long-term trends that can be seen in all democratic countries. They concern the identity and functions of political parties. In order to gradually consolidate their position in the institutions, the parties emphasised their role as "vote-hunters". To maximise their vote, the political parties turned to all voters and adopted a rather vague stance, failing to clearly define their identity.

This led to a neutralisation of their political manifesto. The parties started to look alike because they developed similar programmes. While the traditional parties played down the problem of identity (Prospero 2009: 457), populists offered a principle of identification, that of the "mythical people", filling an unsatisfied demand. The transformation of the political parties, therefore, made it possible for populist challengers to enter the arena.

However, in recent decades, the grip of political parties on society has become weaker. The number of registered political parties has decreased. The rate of party membership fell from 10.43 to $3.72 \%$ between 1976 and 2006 (Fruncillo 2009) ${ }^{13}$. This is considered an indicator of the degree of social integration of the parties. However, the weakening of organised parties is only one aspect of the decline of their social roots.

The spread and intensity of feelings of closeness to political parties are the most eloquent symptoms of the credit enjoyed by parties. In 1972, according to the results of a survey, $71.5 \%$ of Italian voters felt close to a party. In 2001, about three decades later, the percentage of those who claimed they felt close to a party amounted to just $54.8 \%$ (Table 1). In 2008, this figure fell by a further 3.6 points.

\footnotetext{
${ }^{13}$ The membership rate is calculated as the total number of party members divided by the total number of eligible voters in an election year multiplied by 100 .
} 
Table 1. Closeness to a Political Party. Distribution of Respondents according to Closeness to a Political Party in 2001 and in 2008

\begin{tabular}{|l|c|c|c|c|}
\hline & $\mathbf{2 0 0 1}$ & & $\mathbf{2 0 0 8}$ & \\
\hline No & 42.2 & & 46.4 & \\
\hline Yes & 54.8 & & 51.2 & \\
\hline Don't know & 1.7 & & 1.7 & \\
\hline No answer & 1.3 & & 0.7 & \\
\hline Total & 100.0 & & 100.0 & \\
\hline N & 3209 & & 3000 & \\
\hline (If Yes) & & & & \\
\hline Very close & & 19.9 & & 15.5 \\
\hline Fairly close & & 41.2 & & 30.1 \\
\hline Only a sympathiser & & 38.6 & & 53.4 \\
\hline Don't know & & 0.2 & & 0.9 \\
\hline No answer & & 0.1 & & 0.1 \\
\hline Total & & 100.0 & & 100.0 \\
\hline N & & 1758 & & 1545 \\
\hline
\end{tabular}

Source: Itanes 2001, 2008 $8^{14}$.

Notes: Text of the questions: "Is there any political party that you feel closer to than others? Yes, No, Don't know, No answer". (If yes) "Would you consider yourself very close, fairly close to this party or only a sympathiser? Don't know, No answer"

Furthermore, the lower diffusion of feeling of closeness has been accompanied by a drop in its temperature. The percentage of those who feel very or fairly close to a party also decreased, while respondents who consider themselves to be mere sympathisers has increased. The weakening of the emotional and psychological ties between citizens and parties is also shown by the percentage of voters who say they have a lot or enough confidence in political parties. This was equal to $20.6 \%$ in 2001 and fell to $18.4 \%$ in 2008 (Table 2).

Table 2. Trust in Political Parties in 2001 and 2008

\begin{tabular}{|l|c|c|}
\hline & $\mathbf{2 0 0 1}$ & $\mathbf{2 0 0 8}$ \\
\hline Not at all & 26.8 & 26.1 \\
\hline A little & 49.5 & 49.9 \\
\hline Not at all+a little & 76.3 & 76.0 \\
\hline Some what & 19.2 & 16.9 \\
\hline Very much & 1.4 & 1.5 \\
\hline Some what + very much & 20.6 & 18.4 \\
\hline Don't know & 2.7 & 5.2 \\
\hline No answer & 0.4 & 0.4 \\
\hline Total & 100.0 & 100.0 \\
\hline $\mathbf{N}$ & 3209 & 3000 \\
\hline
\end{tabular}

Source: Itanes 2001, 2008.

Notes: Text of the questions: "Now, please tell me how much you trust each of the following institutions (i.e. very much, somewhat, a little, not at all, don't know, no answer): Political Parties."

${ }^{14}$ This table, and those which follow, are based on data collected by the Italian National Election Studies (ITANES) Association, in 2001 and 2008, and downloaded from the Association's web site (http://www.itanes.org/dati/). 
This is a recurring topic in political debates and press reports. It is used to emphasise the divorce between political parties and society. On the basis of these empirical findings, the spread of populism can be connected to the weaker hold the parties have on citizens. The crisis of the party-dominated system and the transformation of political parties led the way to populism, with the decline of traditional parties being unstoppable due to the well-aimed blows of the populists. The relation is circular: the decline of party settlement has allowed the populist outsiders to enter, but the populists' campaigns have further weakened their credibility.

The populist outsiders make the political parties the targets of their controversy for different reasons. First, a new force on the electoral market signals its originality by, amongst other things, highlighting the deficiencies of those who are in control, i.e. the political parties. In addition to these tactical considerations, there are other deeper reasons. Populism is "an appeal to the people against the stabilised structure of power" and against the "corrupt élite". Despite the crisis of legitimacy, the parties are still well-established in the political institutions (Ignazi 2012). Moreover, politicians are still selected by the parties, perhaps through procedures other than those of the past, such as primaries. This trend is only partially open to political personalities who have built their cursus honorum outside the parties ${ }^{15}$. Some recent investigations by magistrates indicate that corruption linked to public spending has not been eradicated, providing the populist political forces a quiver full of arrows.

In short, even in Italy, the parties have become removed from society, their representative power weakened and the populists have been able to claim that they are the defenders of the people. When the parties have become more and more similar to each other in political and ideological terms (Mair 2002: 88), their political identity has been "neutralised" (Mair 2002: 88-92). It has been easy for the populists to claim that the parties are all the same and selfreferential and to challenge the unwarranted privileges of an undifferentiated political class.

A further reason for the aversion of populists to political parties is their impatience with the mediated politics of bureaucratic structures. In the years of establishing democracy and inclusion of the working class, the representative institutions and party organisations had been the instrument through which the "newly-included" citizens could influence political decisions (Calise 1994). These structures have gradually become more complex and are articulated in a myriad of levels and layers, in some cases not readily accessible to ordinary citizens. The populists have highlighted the distance between these structures and the preferences of the people, claiming that they have been deprived of their opportunity to make their voices heard. The parties are therefore disliked by the populists for their bureaucratic organisation and especially because they are the cornerstone of representative politics in its most recent configuration (Taggart 2002: 145).

\footnotetext{
15 Apart from Silvio Berlusconi, a businessman, the most important name is that of Azelio Ciampi, who became Prime Minister when he was Governor of the Italian Central Bank. He was then minister several times, before becoming President of the Republic.
} 
The criticism aimed at political parties as bureaucratic structures ends up impacting on the structures of representation per se. It seems to achieve some success as is apparent from the level of trust in Parliament, the representative institution par excellence.

Table 3. Trust in Parliament in 2001 and 2008

\begin{tabular}{|l|c|c|}
\hline & $\mathbf{2 0 0 1}$ & $\mathbf{2 0 0 8}$ \\
\hline Not at all & 11.2 & 15.8 \\
\hline A little & 38.3 & 42.8 \\
\hline Not at all+a little & 49.5 & 58.6 \\
\hline Some what & 39.4 & 29.1 \\
\hline Very much & 6.4 & 5.3 \\
\hline Some what + very much & 45.8 & 34.4 \\
\hline Don't know & 4.4 & 6.6 \\
\hline No answer & 0.3 & 0.4 \\
\hline Total & 100.0 & 100.0 \\
\hline $\mathbf{N}$ & 3209 & 3000 \\
\hline
\end{tabular}

Source: Itanes 2001, 2008.

Notes: Text of the question: "Now, please tell me how much you trust each of the following institutions (i.e. very much, some what, a little, not at all, Don't know, No answer):Parliament"

In fact, in 2001, less than half $(45.8 \%)$ claimed to have a lot or enough trust in Parliament, with this becoming little more than a third (34.4\%) in 2008, only seven years later (Table 3). The level of confidence in Parliament is still higher than that in political parties, but the downward trend is obvious and significant. This can be interpreted as a result of the establishment of a thin populist ideology that opposes traditional structures of representation.

Therefore, populism has been expressed in the form of "protest against" the élites and stabilised structures of power, just as it has mobilised popular support against the traditional parties. However, when populist ideology keeps it distance from representative politics, it not only expresses an aversion to someone and something, but also encodes a "positive" idea of a certain type of relationship between the people and the decision-makers (Mair 2002: 88). Populism proposes a specific form of democracy when it focuses on the legitimation of power, relations and the links between rulers and the ruled (ibid). In particular, populism presents itself as "popular democracy without parties" that is structured on the "direct relationship of trust between the people and the leaders" (ibid).

Thus, in the positive proposal of populism, the role of the leader is central to the construction of political relations and decisions. Regarding this aspect, there seems to be increasing receptiveness among Italian voters. In fact, in $2001,68.6 \%$ of the respondents stated that they supported the need for a strong leader in Italy. This share of the electorate, already very high, rose to $76.3 \%$ in 2008. More than three out of four voters favoured a strong leader in Italy. In 2008, nearly half of respondents strongly agreed with this statement (Table 4). 
Table 4. Agreement on the Need for a Strong Leader in Italy

\begin{tabular}{|l|c|c|}
\hline & $\mathbf{2 0 0 1}$ & $\mathbf{2 0 0 8}$ \\
\hline Disagree completely & 12.3 & 10.1 \\
\hline Agree a little & 13.7 & 9.5 \\
\hline Disagree completely+ Agree a little & 26.0 & 19.6 \\
\hline Agree fairly & 34.8 & 27.2 \\
\hline Agree completely & 33.8 & 49.1 \\
\hline Agree fairly+ completeley & 68.6 & 76.3 \\
\hline Don't know & 5.2 & 3.9 \\
\hline No answer & 0.2 & 0.2 \\
\hline Total & 100.0 & 100.0 \\
\hline $\mathbf{N}$ & 3209 & 3000 \\
\hline
\end{tabular}

Source: Itanes 2001, 2008.

Notes: Text of the question: Now, I shall read some opinions often people hold on politics and economics. Please, tell me how much do you agree with each of them? (Agree completely Agree fairly Agree a little Disagree completely, Don't know No answer) Today Italy needs a stronger leader.

Obviously, this result can be interpreted in different ways. It is even possible to believe that it expresses a desire for a quasi-authoritarian strengthening and concentration of power. However, the most plausible hypothesis is that citizens wish for the presence of a leader capable of freeing himself or herself from the constraints of discredited and self-referential "collective bodies" so as to quickly make decisions that are closer to the needs of the people.

In the face of the crisis of the political parties, the role of the leader in the structure of electoral choice has become much more important. In 1972, 51\% of respondents indicated a political party as the main factor in their vote; only $9.7 \%$ in 2008 said they had voted for a party and $8.8 \%$ for a coalition. By contrast, in 2001, a fifth of the electorate reported having based their choice on the coalition leader and in 2008, 29.3\% of the respondents said that they had reached a decision taking into account the coalition leader $(12.1 \%)$ or party leader (17.2\%).

For the populists, the leader is not simply the tool to intercept the consent of the voters. In a populist thin ideology, the valorisation of the function of the leader calls upon deeper issues that concern the very 'idea' of democracy. Populist appeals against the political class, the establishment and institutions of representation favour speed and immediacy. Populists hate wasting time and despise rituals, along with the tendency towards mediation. "Populism [...] is defined by a relationship with time which is in complete opposition to normal political time" (Hermet 2001: 50). Normally, in politics, it is impossible to satisfy all demands and commitments, and reconciling them requiring a careful and lengthy assessment (ibid). On the contrary, populists claim to provide immediate answers to problems, so they tend to simplify processes through which solutions are implemented and decision-makers selected.

Essentially, populism does not question the principle of representation, but rather representative politics. Populists do not clamour for direct democracy, but advocate a political practice that makes use of the instruments of direct 
democracy. Populist democracy is not direct, but is based on immediacy, since it wants to save time, streamline processes and reduce the levels of government involved in making decisions. "The basic message of every form of populism is its refusal of mediations that are judged useless, superfluous, limiting or harmful" (Taguieff 2003: 85).

In this perspective, an emphasis on leadership is a solution to complex political processes (Taggart 2002: 170). For populists, the leader "being an authentic interpreter of the popular will, [...] is responsible for responding in some way to immediate problems, thus replacing long and articulated political procedures" (Crosti 2004: 431). In a populist perspective, the leader incarnates the people, and does not merely represent them, and for this becomes custodian of the same positive virtues of the people (Zanatta 2002: 332). The presence of the leader, therefore, allows to be eliminated several intermediate levels of government that encumber political practices.

The analysis has highlighted the extent to which the spread of certain opinions amongst Italian voters may be linked to the pars destruens of populist ideology: aversion to political parties, structures of power and the corrupt élite as well as to the structures and operating logic of representative politics. They may also be linked with its pars costruens: the need for a strong leader capable of embodying the feelings and demands of a people and transforming them into political decisions.

The concluding part of this analysis aims at testing the hypothesis that populism has also penetrated the Left in Italy. This issue can be addressed by examining hostility towards foreigners, a position that characterised the first expressions of populist politics, which were undoubtedly situated to the Right of the political spectrum.

As expected, a relatively high percentage of respondents consider immigrants to be a threat to their culture and identity. However between 2001 and 2008, this share remained stable $(30.4 \%$ in 2001 and $31.8 \%$ in 2008), despite some populist actors having constantly emphasised this theme (Table 5). The argument that immigrants are a threat to the employment opportunities of Italian citizens fares no better, since the percentage of those who agree to some extent with this statement was $54.2 \%$ in 2001 and $54.1 \%$ in 2008 . The number of people sensitive to appeals against the "enemies of the people", where the latter is understood as a nation or specific community, does not seem to have increased. 
Table 5. Agreement with the Phrase "Immigrants are a Threat"... a) to our Culture and Identity... b) to Employment

\begin{tabular}{|l|c|c|}
\hline a) to our culture and identity & $\mathbf{2 0 0 1}$ & $\mathbf{2 0 0 8}$ \\
\hline Agree completely & 14.2 & 18.3 \\
\hline Agree fairly & 25.2 & 21.2 \\
\hline Agreee fairly+ completeley & 39.4 & 39.5 \\
\hline Agree a little & 27.9 & 24.4 \\
\hline Disagree completely & 30.4 & 31.8 \\
\hline Disagree completely+ Agree a little & 58.3 & 56.2 \\
\hline Don't know & 2.1 & 3.8 \\
\hline No answer & 0.2 & 0.5 \\
\hline Total & 100.0 & 100.0 \\
\hline N & 3209 & 3000 \\
\hline b) to employment & & \\
\hline Agree completely & 18.4 & 19.7 \\
\hline Agree fairly & 25.6 & 22.9 \\
\hline Agree fairly+ completeley & 44.0 & 42.6 \\
\hline Agree a little & 28.3 & 24.3 \\
\hline Disagree completely & 25.9 & 29.8 \\
\hline Disagree completely+ Agree a little & 54.2 & 54.1 \\
\hline Don't know & 1.6 & 3.0 \\
\hline No answer & 0.2 & 0.3 \\
\hline Total & 100.0 & 100.0 \\
\hline N & 3209 & 3000 \\
\hline Sourc: Itrat & &
\end{tabular}

Source: Itanes 2001, 2008.

Notes: Text of the questions: 2001 - "How much do you agree with the following statements? (Agree completely Agree fairly Agree a little Disagree completely Don't know No answer) a) Immigrants are a threat to our culture and identity b) Immigrants are a threat to employment"; 2008 - "Now, I shall read some opinions often people hold on politics and economics. Please, tell me how much do you agree with each of them? (Agree completely Agree fairly Agree a little Disagree completely, Don't know No answer) a) Immigrants are a threat to our culture and identity b) Immigrants are a threat to employment".

Hostility toward immigrants is the hallmark of right-wing populism (Tarchi 2015). One of the objectives of this paper is to assess whether a thin populist ideology has spread amongst voters according to their general orientation on the left-right axis. It is helpful to start with the aforementioned issue of hostility towards migrants. It is useful to observe the distribution of respondents concerning to their adherence to the view that migrants are a threat, according to their self-location along the left-right axis.

To facilitate this comparison, an index was developed: the position of greatest hostility towards immigrants is represented by agreement with both statements, i.e. that immigrants are a threat to culture and employment. That of greater openness is represented by disagreement with both statements. The two intermediate positions refer to those who agree with only one of the two statements.

Between 2001 and 2008, there was no significant change in the percentage of respondents at the two extremes of the index (Table 6). The percentage of those who consider immigrants to be only a threat to employment decreased, 
whilst the percentage of those who believe that immigrants can erode Italian identity increased.

Among right-wing voters, strong agreement with both statements prevails, whereas those on the Left tend to disagree with both. Interestingly, the highest levels of concern regarding immigrants are found amongst those who could not situate themselves along the left-right axis. This includes those who did not know how to situate themselves as well as those who refused to place themselves. Inspection of the distribution of respondents according to other characteristics included in the definition of populism adopted in this work (closeness to parties, trust in Parliament, agreement with the need for a strong leader) seems to confirm that this group is particularly susceptible to populist appeals.

To evaluate the attachment to political parties, an index that considers both the feeling of closeness to a party and trust in political parties was developed. High values identify those who feel close to a party and have confidence in political parties, whereas lower values identify those who do not feel close to a party and have little or no faith in political parties. Intermediate values were therefore assigned to those who feel close to a party but have little faith in political parties.

Among those who did not position themselves along the left-right axis, there is a large number who do not feel close to a party and have little faith in political parties. This can also be found among those who said they did not know how to position themselves, as well as those who refused to situate themselves. In the first case, we are dealing with citizens who are not able to respond to the question, not only due to their lack of skill, but also because they cannot differentiate among parties offering similar organisational models or similar policy proposals. In the second case, we are dealing with citizens who do not want to be placed along this axis because they consider it to be a legacy of the past and not adequate for current society.

The second consideration is that between 2001 and 2008, there was a disproportionate increase in the percentage of left-wing voters with a weak attachment to parties and a low level of trust in Parliament, along with those who say they strongly agree with the need for a strong leader. Above all between 2001 and 2008, it seems that the percentage of those who agree to some extent with the need for a strong leader increased by 7.1 points, while among left-wing voters it increased by 10.7 points. The proportion of left-wing voters who are more tolerant towards migrants and less concerned about their presence even increased between 2001 and 2008.

There is no similar trend regarding the negative attitudes toward the immigrants, a theme strongly supported by the right-wing populist movements. Indeed the proportion of left-wing voters who are more tolerant towards migrants and less concerned about their presence is increased between 2001 and 2008. 
Table 6. Distribution of Respondents according to Self-position on the Left-Right Axis and According to the Index of Agreement about the Items "Immigrants are a Threat to our Culture and a Threat to Employment", to the Index of Attachment to Political Parties, to Trust in Parliament, to the Agreement about the Need for a Strong Leader

\begin{tabular}{|c|c|c|c|c|c|c|c|c|c|c|c|c|}
\hline \multirow{3}{*}{$\begin{array}{l}\text { Variable's label } \\
\text { (b) }\end{array}$} & \multicolumn{12}{|c|}{ Self-position on the Left-right Axis ${ }^{\text {(a) }}$} \\
\hline & \multicolumn{6}{|c|}{2001} & \multicolumn{6}{|c|}{2008} \\
\hline & Left & Center & Right & $\mathrm{DK}^{(\mathrm{h})}$ & NA (i) & Tot & Left & Center & Right & DK (8) & NA (9) & Tot \\
\hline \multicolumn{13}{|l|}{$\begin{array}{l}\text { Immigrants are a } \\
\text { threat (index) }\end{array}$} \\
\hline No & 59.2 & 46.0 & 35.8 & 33.6 & 39.2 & 45.3 & 69.5 & 46.3 & 27.8 & 31.3 & 41.9 & 44.9 \\
\hline $\begin{array}{l}\text { Only to } \\
\text { employment }\end{array}$ & 11.2 & 17.2 & 13.4 & 14.4 & 16.8 & 14.0 & 6.6 & 14.6 & 11.9 & 10.6 & 10.7 & 11.1 \\
\hline $\begin{array}{l}\text { Only to our } \\
\text { culture and } \\
\text { identity }\end{array}$ & 7.7 & 10.4 & 11.3 & 9.2 & 7.4 & 9.5 & 10.2 & 14.4 & 15.3 & 17.1 & 13.0 & 13.8 \\
\hline $\begin{array}{l}\text { Both: our culture } \\
\text { and employment }\end{array}$ & 21.9 & 26.4 & 39.5 & 42.8 & 36.6 & 31.2 & 13.7 & 24.7 & 45.0 & 41.0 & 34.4 & 30.1 \\
\hline $\mathrm{N}$ & 926 & 728 & 922 & 250 & 273 & 3099 & 714 & 827 & 799 & 339 & 131 & 2810 \\
\hline \multicolumn{13}{|l|}{$\begin{array}{l}\text { Index of } \\
\text { attachment to } \\
\text { political parties } \\
\text { (e) }\end{array}$} \\
\hline High & 29.3 & 16.0 & 22.4 & 17.7 & 9.6 & 21.5 & 23.4 & 16.1 & 23.9 & 10.9 & 9.8 & 19.3 \\
\hline Medium & 48.6 & 30.3 & 52.9 & 18.6 & 10.0 & 40.2 & 51.2 & 32.5 & 48.6 & 13.8 & 15.4 & 39.0 \\
\hline$H+M$ & 77.9 & 46.3 & 75.3 & 36.3 & 19.6 & 61.7 & 74.6 & 48.6 & 72.5 & 24.7 & 25.2 & 58.3 \\
\hline Low & 22.1 & 53.7 & 24.7 & 63.7 & 80.4 & 38.3 & 25.4 & 51.4 & 27.5 & 75.3 & 74.8 & 41.7 \\
\hline $\mathrm{N}$ & 915 & 708 & 923 & 215 & 261 & 3022 & 713 & 825 & 785 & 320 & 123 & 2766 \\
\hline \multicolumn{13}{|l|}{$\begin{array}{l}\text { Trust in } \\
\text { Parliament }\end{array}$} \\
\hline $\begin{array}{l}\text { High (Very much } \\
\text { and somewhat) }\end{array}$ & 54.2 & 49.8 & 47.5 & 35.9 & 35.1 & 48.1 & 38.0 & 33.5 & 44.0 & 26.7 & 35.1 & 36.9 \\
\hline
\end{tabular}




\begin{tabular}{|c|c|c|c|c|c|c|c|c|c|c|c|c|}
\hline $\begin{array}{l}\text { Low (a little. not } \\
\text { at all) }\end{array}$ & 45.8 & 50.2 & 52.5 & 64.1 & 64.9 & 51.9 & 62.0 & 66.5 & 56.0 & 73.3 & 64.9 & 63.1 \\
\hline $\mathrm{N}$ & 921 & 721 & 923 & 223 & 271 & 3059 & 711 & 832 & 796 & 315 & 131 & 2785 \\
\hline \multicolumn{13}{|l|}{$\begin{array}{l}\text { Agreement on } \\
\text { the need for a } \\
\text { strong leader }^{(g)}\end{array}$} \\
\hline $\begin{array}{l}\text { Low (Disagree } \\
\text { completely Agree } \\
\text { a little) }\end{array}$ & 47.7 & 27.9 & 8.6 & 19.6 & 28.0 & 27.5 & 37.0 & 20.6 & 5.5 & 18.2 & 29.3 & 20.4 \\
\hline Agree fairly & 32.2 & 38.5 & 38.8 & 39.7 & 39.0 & 36.8 & 27.5 & 31.2 & 26.9 & 29.1 & 22.6 & 28.4 \\
\hline Agree completely & 20.2 & 33.6 & 52.6 & 40.7 & 33.0 & 35.7 & 35.6 & 48.2 & 67.6 & 52.7 & 48.1 & 51.2 \\
\hline $\begin{array}{l}\text { Fairly+ } \\
\text { completely }\end{array}$ & 52.3 & 72.1 & 91.4 & 80.4 & 72.0 & 72.5 & 63.0 & 79.4 & 94.5 & 81.8 & 70.7 & 79.6 \\
\hline \multirow[t]{2}{*}{$\mathrm{N}$} & 917 & 723 & 916 & 215 & 261 & 3033 & 717 & 850 & 829 & 347 & 133 & 2876 \\
\hline & 100.0 & 100.0 & 100.0 & 100.0 & 100.0 & 100.0 & 100.0 & 100.0 & 100.0 & 100.0 & 100.0 & 100.0 \\
\hline
\end{tabular}

Source: Itanes 2001, 2008.

Notes: a) Text of the question: "A lot of people talk about politics using the terms "left" and "right". On this card, there is a row of boxes that go from left to right.

Thinking of your political views, in which box would you be? "Left, from 1 to 4; Centre 4-5; Right from 7 to 10.

b) The text of the questions used to construct the synthetic indices is provided in the previous tables $1,2,3,4,5$

c) The index of attachment to a political party is created by taking into account two questions. a) "Is there a political party to which you feel closer than the others?"; b) "Can you say how much confidence you have in these institutions? (None, little, enough, a lot of faith) ... Parties " Low = does not feel close to a party and has little or no trust in political parties; medium = feels close to a party, but has little or no confidence in a party; high = feels close to a party and feels very or fairly confident in a party.

d) For 2001, Pearson's Chi squared: 152.81 (12 degrees of freedom, $\mathrm{p}<0.000$ ); for 2008, Pearson's Chi squared: 341.61 ; 12 degrees of freedom 12, $\mathrm{p}<0.000$

e) For 2001, Pearson's Chi squared: 518.04 (8 degrees of freedom, $\mathrm{p}<0.000$ ); for 2008, Pearson's Chi squared: $382.04 ; 8$ degrees of freedom 12, p < 0.000

f) For 2001, Pearson's Chi squared: 44.44 (4 degrees of freedom, $p<0.000$ ); for 2008, Pearson's Chi squared: $35.81 ; 4$ degrees of freedom, $p<0.000$

g) For 2001, Pearson's Chi squared: 405.01 (8 degrees of freedom, $\mathrm{p}<0.000$ ); for 2008, Pearson's Chi squared: 275.91 ; 8 degrees of freedom 12, p < 0.000

h) $\mathrm{DK}=$ Don't Know

i) $\mathrm{NA}=$ Not answer or not want to answer 


\section{Conclusions}

The analysis carried out in this article leads to some final, but provisional, conclusions. Populism is a "thin ideology", a set of general ideas that can be integrated with strong and structured ideologies. It is primarily an appeal to the people against its enemies who are, on the one hand, foreigners and, on the other, the corrupt élite. This aversion is manifested through controversy against the political parties, which are considered a cornerstone of power structures and the main subjects of representative politics. Populism is hostile to representative politics, those who are involved in this process and criticise the length of time and complexity of procedures that it entails. On the positive side, populism prefers an immediate and non-mediated politics in which mediations leading to political decisions are absent or minimised.

In this perspective, the emphasis is on the figure of a leader who embodies the virtues of the people and the corresponding exclusion of collective bodies as actors of political mediation. Populism is thus a "thin ideology" that prefigures a "democracy without parties", where political relations and the formation of decisions take place through a direct and immediate relationship between the people and the leaders. In this logic, three elements were analysed in this paper. The first is distrust of immigrants, an issue that has negatively characterised populist movements, especially those which interpret the people as a nation or ethnic community. The second aspect comes from an aversion to representation and has been analysed through the closeness of citizens to political parties. The third aspect is the demand for a strong leader. I showed that voters with different ideological outlooks have different patterns of responses in relation to these three dimensions.

In the first part of the paper, I described the characteristics of various Italian political formations that have been labelled populist and which are on the Right or Left of the political spectrum (or shy away from this traditional framing). The results partially confirm the recent hypothesis of Kriesi (2014). He analysed the three concepts of "the people" identified by Mény and Surel (2004: 173-196) ${ }^{16}$ alongside the left-right positioning of respondents. The concept of "people-class" was matched to a left-wing orientation, the "peoplenation" concept could be linked with a right-wing orientation, whilst the "people as sovereign" was considered an expression of "genuinely populist" forces. Among right-wing voters - prone to accepting a notion of the people as a nation - there was the fairly common attitude of closure towards immigrants and willingness to accept a strong leader as guarantor of national identity. Among voters who did not position themselves on the left-right spectrum, there were higher percentages of respondents with a weaker attachment to political parties, less trust in Parliament, a relatively high concern towards the immigrants and a stronger belief in strong leaders.

The reasoning becomes more complicated when referring to respondents who situate themselves to the Left of the political spectrum. The left-wing political forces have abandoned - more or less explicitly - the old classist

${ }^{16}$ Please refer to note 1 
conception and call for a radical transformation of society that favours disadvantaged citizens. Voters who are in this part of the political space appear to be less susceptible to populist appeals. It is therefore no coincidence that left-wing political formations that have used this kind of appeal to the people, so far, have received a much smaller share of the vote, when compared with right-wing parties or with those which are difficult to situate.

Populist appeals that valorise the role of leadership nevertheless seem to have become more popular among left-wing voters. Recently, the Democratic Party leader, heir of the old mass parties, has been accused of emphasising strong leadership and populism. The importance of leaders in electoral contests is now recognised by all scholars, and it is accepted that citizens frequently vote for populist and charismatic leaders (Calise 2010: 140-145), based on "a feeling of identity, capable of creating and reinforcing a relationship with the leader which can even be authoritarian" (ibid: 144). In addition, based on the results of this analysis, it is possible to identify a growing emphasis on leaders in the overall dynamics of political decision-making, with consequences for the circuit of representation and political accountability.

\section{References}

Calise M (ed) (1992) Come cambiano i partiti [How the political parties change]. Bologna: Il Mulino.

Calise M (1994) Dopo la partitocrazia [After the partitocracy]. Turin: Einaudi.

Calise M (1998) La costituzione silenziosa [The silent constitution]. Rome: Laterza.

Calise M (2010) Il partito personale [The personal political party]. Rome: Laterza.

Canovan M (1981) Populism. New York-London: Harcourt Brace Jovanovich.

Canovan M (1993) Il populismo come l'ombra della democrazia [Populism as the shadow of democracy]. Europa/Europe 2(1993): 43-62.

Canovan M (1999) Trust the People! Populism and two face of Democracy. Political Studies XLVII: 2-16.

Cotta M, Isernia P (Eds) (1996) Il gigante dai piedi d'argilla. Le ragioni della crisi della prima Repubblica: partiti e politiche dagli anni '80 a Mani pulite [The giant with feet of clay. The reasons for the crisis of the first republic: Political Parties and public policies from the late 80s to Mani Pulite]. Bologna: Il Mulino.

Crosti M (2004) Per una definizione del populismo come antipolitica. [For a definition of populism as anti-politics]. Ricerche di storia politica a. VII(3): 425443.

Dalton R J (1984) Cognitive mobilization and partisan dealignment in advanced industrial democracies. The Journal of Politics 46(1): 264-284.

Decker F (2003) The populist challenge to liberal democracy. Internationale Politik und Gesellschaft - International Politics and Society 3: 47-59.

Di Tella TS (1997) Populism into the twenty-first century. Government and Opposition 32(2 April): 187-200.

Fruncillo D (2004) Urna del silenzio. L'astensionismo elettorale in Italia [The Silent ballot box: Electoral abstentionism in Italy]. Rome: Ediesse.

Fruncillo D (2009) Il solstizio d'inverno. Il rapporto tra partiti ed elettori in Italia [The winter solstice. The relationship between political parties and voters in Italy]. Democrazia e Diritto a. XLVI (3-4): 47-81. 
Galli G (1966) Il bipartitismo imperfetto: comunisti e democristiani in Italia [Imperfect bipartitism: communists and christian democrats in Italy]. Bologna: Il Mulino,

Gellner E, Ionescu G (eds) (1969) Populism: Its meanings and national characteristics. London: Weidenfeld-Nicholson.

Hermet G (2001) Les populismes dans le monde. Une histoire sociologique. XIC e-XX siècle [Populism in the world. A sociological history. XIX and XX century]. Paris: Fayard.

Ignazi P (2012) Forza senza legittimità. Il vicolo cieco dei partiti [Power without legitimacy. The political parties in a blind alley]. Rome: Laterza.

Jones E (2007) Populism in Europe. Sais Review XXVII (1, Winter-Spring): 37-47.

Katz R S, Mair P (1995) Changing models of party organization and party democracy: the emergence of the Cartel Party. Party Politics I(1): 5-28.

Kitschelt H (1988) Left-libertarian parties: Explaining innovation in competitive party systems. World Politics 40: 194-234.

Knutsen O (1998) Expert judgements of the left-right location of political parties: A comparative longitudinal study. West European Politics 21(2): 63-94.

Kriesi H (2014) The populist challenge. West European Politics 37(2): 361-378.

Lijphart A (2001) Le democrazie contemporanee [Contemporary democracy]. Bologna: il Mulino.

Lowi T J (1992) Governo di partito e regime presidenziale [Party government and presidentialism]. In Come cambiano i partiti, M Calise (ed), 299-322. Bologna: Il Mulino.

Mair P (1992) La trasformazione del partito di massa in Europa [The transformation of the mass party in Europe]. In Come cambiano i partiti, M Calise (ed), 99-120. Bologna: Il Mulino.

Mair P (2002) Populist democracy vs. party democracy. In Democracies and the populist challenge, Y Mény, Y Surel (eds), 81-98. New York: Palgrave.

Mastropalo A (2000) Antipolitica. All'origine della crisi italiana [Anti-politics. The origin of the Italian crisis]. Neaples: Ancora del Mediterraneo.

Mastropaolo A (2005) La mucca pazza della democrazia. Nuove destre, populismo, anti-politica [The mad cow of democracy. new right, populism, anti-politics]. Turin: Bollati Boringhieri.

Mazzoleni G, Stewart J, Horsfiled B (eds) (2003) The media and neo-populism: a contemporary comparative analysis. Westport-London: Praeger Publishers.

Mazzoleni G, Sfardini A (2009) Politica Pop. Da "Porta a Porta a "L'isola dei famosi" [Pop Politics. from "Porta a porta" to "Isola dei famosi"]. Bologna: Il Mulino.

Mény Y (2004) La costitutiva ambiguità del populismo [The constitutive ambiguity of populism]. Filosofia politica a. XVIII(3): 359-376.

Mény Y, Surel Y (2002) La costitutiva ambiguità del populismo [The constitutive ambiguity the populism]. Trasgressioni 34 (gennaio-aprile): 3-13.

Mény Y, Surel Y (eds) (2002) Democracies and the populist challenge. New York: Palgrave.

Mény Y, Surel Y (2004) Populismo e Democrazia [Populism and Democracy]. Bologna: Il Mulino.

Mudde C (2004) The Populist Zeitgeist. Government and Opposition 39(4): 541-563.

Natale P (2014) The birth, early history and explosive growth of the five star movement. Contemporary Italian Politics 6(1): 16-36.

Prospero M (2009) Elogio della mediazione [In praise of mediation]. Democrazia e Diritto a. XLVI (3-4): 385-472. 
Rooduijn M., de Lange SL, van der Brug W (2014) A Populist Zeitgeist? Programmatic Contagion by Populist Parties in Western Europe. Party Politics 20(4): 563-575.

Stanley B (2008) The thin ideology of populism. Journal of Political Ideologies 13: 95-110.

Stetter E (2013) Preface. In The Changing Faces of Populism. Systemic Challengers in Europe and the U.S., H Giusto, D Kitching, S Rizzo (eds). Rome: Lexington Books.

Taggart P (2002) Il populismo [Populism]. Troina: Città Aperta.

Taguieff P A (2003) L'illusione populista [The Populist Illusion]. Milan: Mondadori.

Tarchi M (2003) L'Italia populista. Dal qualunquismo ai girotondi [Populist Italy. From "Qualunquismo" to the "Girotondi"]. Bologna: Il Mulino.

Tarchi M (2004) Il populismo e la scienza politica [Populism and political science]. Filosofia Politica a. XVIII(3): 411-432.

Tarchi M (2015) L'Italia populista. Dal qualunquismo a Beppe Grillo, [Populist Italy. from "Qualunquismo" to Beppe Grillo]. Bologna: Il Mulino.

Wiles P (1969) A syndrome, not a doctrine. Some elementary thesis on populism. In Populism: Its meanings and national characteristics, E Gellner, G Ionescu (eds), 166-179. London: Weidenfeld-Nicholson.

Woods D (2014) The many faces of populism: Current perspectives research. Political Sociology 22: 1-25.

Zanatta L (2002) Il populismo. Sul nucleo forte di un'ideologia debole [Populism. On the strong core of a weak ideology]. Polis XVI(2): 263-292. 
